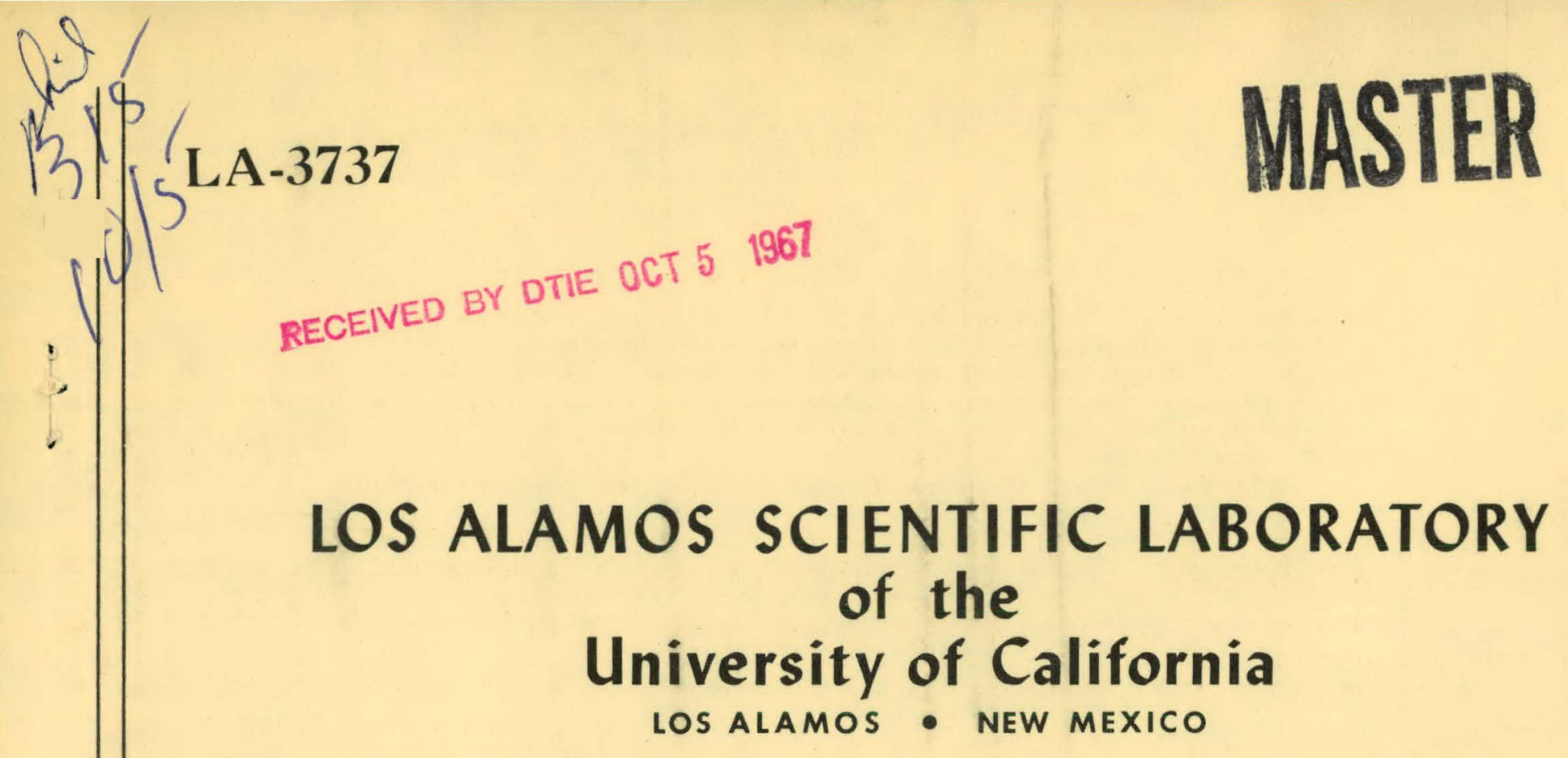

Behavior of Long-Lived Fission Products in Sodium 


\section{DISCLAIMER}

This report was prepared as an account of work sponsored by an agency of the United States Government. Neither the United States Government nor any agency Thereof, nor any of their employees, makes any warranty, express or implied, or assumes any legal liability or responsibility for the accuracy, completeness, or usefulness of any information, apparatus, product, or process disclosed, or represents that its use would not infringe privately owned rights. Reference herein to any specific commercial product, process, or service by trade name, trademark, manufacturer, or otherwise does not necessarily constitute or imply its endorsement, recommendation, or favoring by the United States Government or any agency thereof. The views and opinions of authors expressed herein do not necessarily state or reflect those of the United States Government or any agency thereof. 


\section{DISCLAIMER}

Portions of this document may be illegible in electronic image products. Images are produced from the best available original document. 


\section{LEG A L NOTICE}

This report was prepared as an account of Government sponsored work. Neither the United States, nor the Commission, nor any person acting on behalf of the Commission:

A. Makes any warranty or representation, expressed or implied, with respect to the accuracy, completeness, or usefulness of the information contained in this report, or that the use of any information, apparatus, method, or process disclosed in this report may not infringe privately owned rights; or

B. Assumes any liabilities with respect to the use of, or for damages resulting from the use of any information, apparatus, method, or process disclosed in this report.

As used in the above, "person acting on behalf of the Commission" includes any employee or contractor of the Commission, or employee of such contractor, to the extent that such employee or contractor of the Commission, or employee of such contractor prepares, disseminates, or provides access to, any information pursuant to his employment or contract with the Commission, or his employment with such contractor.

\section{This report expresses the opinions of the author or authors and does not necessarily reflect the opinions or views of the Los Alamos Scientific Laboratory.}

Printed in the United States of America. Available from Clearinghouse for Federal Scientific and Technical Information National Bureau of Standards, U. S. Department of Commerce Springfield, Virginia 22151

Price: Printed Copy $\$ 3.00$; Microfiche $\$ 0.65$ 
LA-3737

UC-80, REACTOR

TECHNOLOGY

TID -4500

H. C. $\$ 2.00$, wn 65

\section{LOS ALAMOS SCIENTIFIC LABORATORY of the University of California LOS ALAMOS - NEW MEXICO}

Report written: June 1, 1967

Report distributed: September 25, 1967

\section{Behavior of Long-Lived Fission Products in Sodium*}

by

J. C. Clifford

*This report is based on a paper presented at the Thirteenth Annual American Nuclear Society Meeting at San Diego, California, June 11-15, 1967.

\section{LEGAL NOTICE}

This report was prepared as an account of Government sponsored work. Nelther the United This report we commission:

A. A. Makes any warranty or representation, expressed contained in this report, or that the use racy, completeness, or usefulness of the in this report may not infringe of any information, apparatus, method, or process disclosed in the report may not infrige privately owned rights; or

B. Assumes any liabilities with respect to the use of, or for damages resuiting from the of any information, apparatus, method, or process discinsed in this report,

As used in the above, "person acting on behalf of the Commission" includes any employee or contractor of the Commission, or employee of such contractor, to the extent that such employee or contractor of the Commission, or employee of such contractor prepares, disseminates, or provides access to, any informatiun pur suant to his employmant nr mnitract with the Commision, or his employment with such contractor. 
THIS PAGE

\section{WAS INTENTIONALLY \\ LEFT BLANK}




\title{
BEHAVIOR OF LONG-LIVED FISSION PRODUCTS IN SODIUM
}

\author{
J. C. Clifford
}

ABSTRACT

\begin{abstract}
Long-lived fission products have been introduced into a small, forced convection sodium loop by immersing a trace-irradiated plutonium alloy in the flowing sodium. The distribution of plutonium, ${ }^{90} \mathrm{Sr},{ }^{137} \mathrm{Cs}$, and ${ }^{155} \mathrm{Eu}$ in the loop, over periods of 1000-3000 h, has been observed by in situ gamma scanning of loop components and by radiochemical analysis of traps and metal specimens removed from the loop. Hot trapping, cold trapping, and graphite adsorber experiments have been conducted.
\end{abstract}

\section{INTRODUCTION}

If the quantities involved are large, the behavior of radioactivity release to sodium coolant from failed or vented reactor fuel elements may limit access to portions of the primary coolant system and may affect the consequences of a loss-of-coolant incident. In such cases, it may be desirable to scavenge fission products (as well as uranium and plutonium) from the coolant.

The work described here is part of a program concerned with the effects of long-time contact between trace-irradiated, plutonium-containing fuels and $500-700^{\circ} \mathrm{C}$ sodium. Assuming that isolated fue 1 failures (without change of state) will occur in a large fast breeder reactor, this program is intended to supply experimental evidence relative to the following questions. (1) Could access to portions of a sodium primary coolant system be restricted because of an accumulation of long-lived, energetic, gamma-emitting fission products? (The problem of mass transport of activated corrosion products from the core area is not considered here). (2) Could fission products and plutonium present in sodium accidentally released from the primary coolant system contribute significantly to external prompt gam- ma dose or to inhalation dose?

Three areas of investigation have been established: (1) mechanisms for release of radioactivity to sodium from fuel at normal operating temperatures, (2) behavior of fission products in sodium, and (3) methods for concentrating activity at selected locations within the primary coolant system. Single isotopes, trace-irradiated $(\mathrm{U}, \mathrm{Pu}) \mathrm{C}$, and irradiated $\mathrm{Pu}-$ Co-Ce alloys are being used in these investigations. Only experiments concerning the behavior of longlived fission products released from $\mathrm{Pu}-\mathrm{Co}-\mathrm{Ce}$ alloy to sodium are presented here.

Because the entire spectrum of fission products could not be examined experimentally, several isotopes were selected on the basis of half-life, yield, and chemical characteristics. These are shown in Table I along with their half-lives and chemical

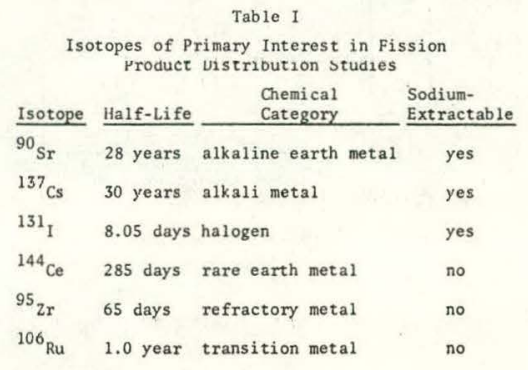


groups. Some isotopes thought to be completely insoluble in sodium have been included, but these will be investigated only until their lack of solubility has been demonstrated.

\section{EXPERIMENTAL TECHNIQUES}

A high purity alloy of plutonium, cobalt, and cerium with a melting point near $435^{\circ} \mathrm{C}$ is used as the source of fission products for the experiments. Contact of this fuel, in the molten state, with sodium rapidly releases the extractable isotopes and has proved a convenient method of introducing fission products into sodium solution.

An open-mouth container partly filled with the liquid fuel alloy is suspended in a forced convection loop, and regions of interest in the loop are monitored using a movable scintillation detector and a multichannel analyzer. The distribution of pure beta emitters and low energy gamma emitters is obtained by radiochemical analysis of metal specimens, sodium, and traps removed from the system.

Figure 1 is schematic of the stainless steel forced-convection loop. The 1oop consists of three vertical legs, a resistance heater, an air heat dump, and a regenerative heat exchanger. The loop

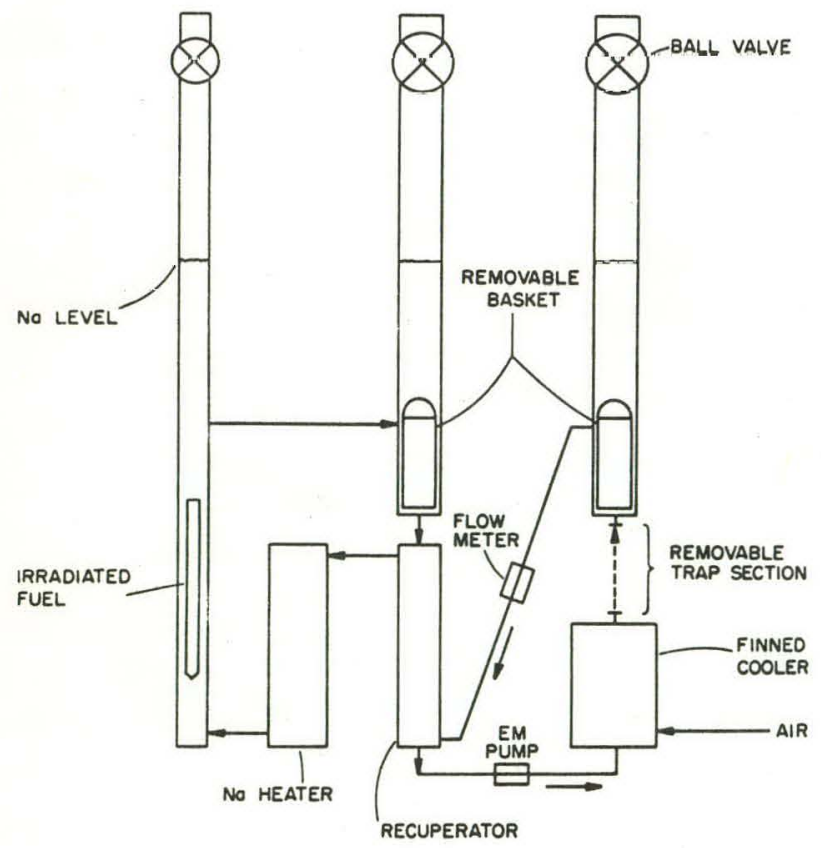

Fig. 1. Forced convection sodium loop. contains approximately $100 \mathrm{in}^{3}$. of sodium flowing at a maximum rate of $300 \mathrm{lb} / \mathrm{h}$. The leg which contains the irradiated fuel is lead-shielded, and fuel is inserted and removed through a gas lock and shielded handling can at its top. The other legs accept metal specimens, which can comprise as much as $25 \%$ of the sodium-wet surface of the system. The loop is operated at $150-600^{\circ} \mathrm{C}$, and the maximum differential is $300^{\circ} \mathrm{C}$. A section of piping above the finned cooler in the cold leg is removable, allowing insertion of traps into the loop.

Because the distribution experiments have used irradiated, stored fuel, no data have been collected for the shorter-lived isotopes ${ }^{131} \mathrm{I}$ or ${ }^{95} \mathrm{Sr}$. New1y irradiated material has not been used because the resolution available with the $3 \times 3$-in. NaI(T1) scintillation detector is not sufficient for detailed analysis of multicomponent gamma spectra. By substituting a solid-state detector and a larger analyzer, a significant increase in resolution can be obtained. The change in resolution is shown in Fig. 2, which compares the spectra obtained from

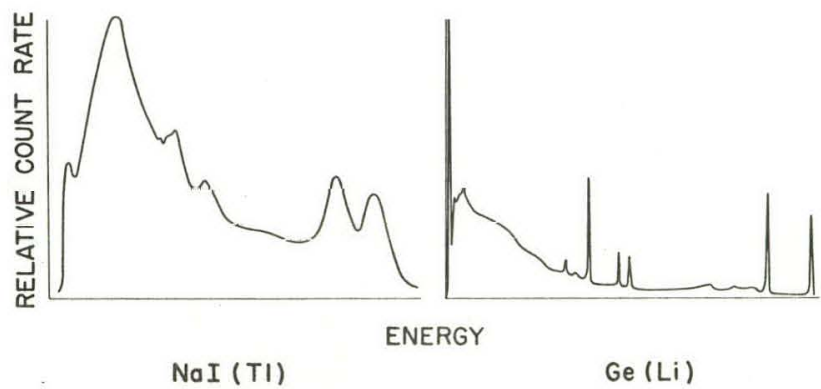

Fig. 2. Gamma spectra obtained with a $3 \times 3$-in. $\mathrm{NaI}(\mathrm{T} 1)$ detector and with a $5-\mathrm{cm}^{3}$ planar $\mathrm{Ge}(\mathrm{Li})$ detector.

irradiated $\mathrm{Pu}-\mathrm{Co}-\mathrm{Ce}$ with the $\mathrm{NaI}$ system and with a $5-\mathrm{cm}^{3} \mathrm{Ge}(\mathrm{Li})$ detector operating in anticoincidence with an annular NaI detector. (The two peaks at the high energy end of each spectrum are $\left.{ }^{60} \mathrm{Co}\right)$. Figure 3 shows the shields, hoists, and cryostat for the movable solid-state system which will be used for higher resolution experiments .

EXPERIMENTAL RESULTS

A. General

The liquid-fuel alloys have provided activity for experiments in which oxygen levels were controlled by a zirconium hot trap, a full-flow cold trap, 


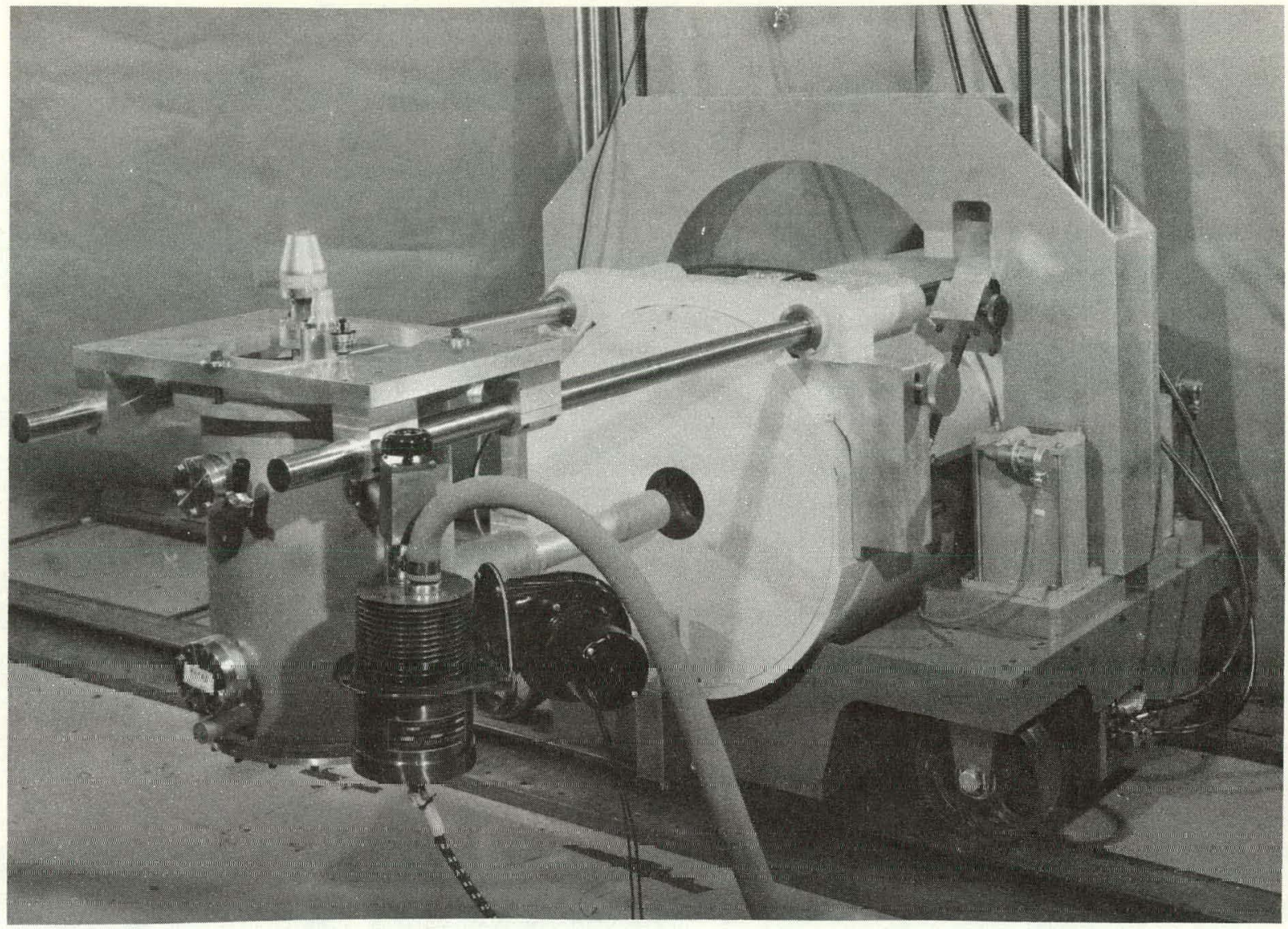

Fig. 3. Shields, cryostat, and hoist for Ge(Li) gamma-ray spectrometer.

or a diffusion cold trap, and for an experiment in which a graphite bed was used to scavenge residual activily from the loop. Information has been obtained for ${ }^{90} \mathrm{Sr},{ }^{106} \mathrm{Ru},{ }^{125} \mathrm{Sb},{ }^{137} \mathrm{Cs},{ }^{144} \mathrm{Ce},{ }^{155} \mathrm{Eu}$, and total plutonium. Table II summarizes the ranges

Table II

Exlremes of Radioactive Contamination Detected After Distribution Experiments

\begin{tabular}{|c|c|c|}
\hline \multirow[b]{2}{*}{ Isotope } & \multicolumn{2}{|c|}{ Range of Contamination } \\
\hline & $\begin{array}{l}\text { In Sodium } \\
(\text { dis/min-g) } \\
\end{array}$ & $\begin{array}{c}\text { On Stainless Steel } \\
\text { (dis/min_in?) }\end{array}$ \\
\hline${ }^{90} \mathrm{Sr}$ & $4 \times 10^{4}-12 \times 10^{4}$ & $8 \times 10^{4}-4 \times 10^{6}$ \\
\hline${ }^{106} \mathrm{Ru}$ & $\overline{<} 100$ & $<200-2300$ \\
\hline $125_{\mathrm{SL}}$ & $\bar{\Xi} 3500$ & $<504600$ \\
\hline${ }^{137} \mathrm{Cs}$ & $2 \times 10^{4}-1.8 \times 10^{6}$ & $2.3 \times 10^{5}-7 \times 10^{7}$ \\
\hline${ }^{144} \mathrm{Ce}$ & $\overline{<} 2$ & $790-5000$ \\
\hline${ }^{155} \mathrm{Eu}$ & $290-2400$ & $9 \times 10^{4}-4 \times 10^{5}$ \\
\hline${ }^{239} \mathrm{Pu}$ & $<1.4 \times 10^{4}$ & $300-3.5 \times 10^{4}$ \\
\hline
\end{tabular}

of contamination levels found in sodium and on stainless steel after $2000-4000 \mathrm{~h}$ of operation in three experiments. The ${ }^{137} \mathrm{Cs},{ }^{90} \mathrm{Sr},{ }^{155} \mathrm{Eu}$, and ${ }^{239} \mathrm{Pu}$ contamination levels were the highest, with ${ }^{137} \mathrm{Cs}$ levels reaching approximately $1 \mu \mathrm{Ci} / \mathrm{g}$ in sodium and 30 $\mu \mathrm{Ci} / \mathrm{in}^{2}$. on stainless steel. The other isotopes were detected in bulk sodium as a few hundred dis/min-g sodium, or less, and were present as surface contamination to the extent of a few thousand dis/min-in? In general, the highest surface contamination levels were observed on stainless steel in the coldest portion of the loop. The lowest levels were in high temperature regions.

The general behavior indicated in the table had been anticipated in light of the chemical characteristics of the species and the results of some distribution experiments performed several years earlier. These earlier experiments consisted of encapsulating the fuel alloy with sodium and irradiating the capsules at 450 and $550^{\circ} \mathrm{C}$. Radiochemical analysis 
showed that approximately $99 \%$ of the ${ }^{137}$ Cs extracted to the sodium phase, along with $90 \%$ of the ${ }^{90} \mathrm{Sr}$ and $95 \%$ of the ${ }^{155} \mathrm{Eu}$. ${ }^{106} \mathrm{Ru}, \mathrm{Ce},{ }^{95} \mathrm{Zr}$, and ${ }^{125} \mathrm{Sb}$ remained behind.

${ }^{90} \mathrm{Sr}$ and ${ }^{137} \mathrm{Cs}$, the species found in greatest abundance in the loop experiments, differed in behavior as shown in Table III. Here, the measured sodium contamination levels at the end of an experiment are compared with the levels which would have existed had all the released activity remained in solution. These latter values appear in the column labelled "Beginning," and were obtained by assuming that $99 \%$ of the ${ }^{137} \mathrm{Cs}$ and $90 \%$ of the ${ }^{90} \mathrm{Sr}$ from the fuel were released to the sodium at the first moment of contact. These upper limit values were compared with the sum of the experimentally determined activities in the system at the end of each test, and the agreement was satisfactory, except for ${ }^{90} \mathrm{Sr}$ in the full-flow cold trap experiment. Apparently the assumed release fractions are realistic, although the release rate, obviously, is not. For the graphite bed experiment, the initial specific activities in Table III are measured values. The time-dependent behavior of ${ }^{137}$ Cs showed that very little change was occurring at the end of each experiment, and the same is assumed to hold for ${ }^{90} \mathrm{Sr}$. of the strontium released during the hot trap experiment, only a small fraction (less than 1/200) remained with the sodium. Essentially no change in strontium level occurred during the graphite scavenger experiment, probably because strontium had been fixed in place in the loop during the previous experiment. ${ }^{137} \mathrm{Cs}$ was not so readily removed from solution as ${ }^{90} \mathrm{Sr}$, and the full-flow $\mathrm{Na}_{2} \mathrm{O}$ trap was the least effective of the ${ }^{137}$ Cs scavenging tech- niques. However, difficulties in controlling the trap temperature may have contributed to this condition.

By describing the individual experiments and their results in more detail it should be possible to present a better qualitative picture of the behavior of ${ }^{137} \mathrm{Cs}$, and of ${ }^{90} \mathrm{Sr}$ as well.

\section{B. Zirconium Hot Trap Experiment}

The experiment using zirconium to control oxygen level consisted of submerging trace-irradiated fuel in the $600^{\circ} \mathrm{C}$ fuel leg and a stainless steel and zirconium foil assembly in each of the other legs. ${ }^{137} \mathrm{Cs}$ was identified in the coldest $\operatorname{leg}\left(500^{\circ} \mathrm{C}\right)$ a few hours after the fuel had been inserted. During a month at constant temperature, the ${ }^{137}$ Cs level in the cold leg decreased slowly. Next, temperatures were lowered to $500^{\circ} \mathrm{C}$ in the fue $1 \mathrm{leg}$ and $300^{\circ} \mathrm{C}$ in the cold leg, and ${ }^{137} \mathrm{Cs}$ activity continued to decrease. Rapid temperature cycling of the cold leg between 300 and $500^{\circ} \mathrm{C}$ had trivial effects on ${ }^{137} \mathrm{Cs}$ activity level and distribution.

As can be seen in Fig. 4, cesium lost from the sodium-filled portion of the cold leg moved into a 3 -in. band above the liquid level. The activity peak coincides with the top of the thermal insulation. Similar ${ }^{137}$ Cs deposits were detected in the other legs. The second ${ }^{137}$ Cs deposit in the cold leg extends axially throughout a 5-in.-1ong tuhe packed with wirc mesh. Cesium was detected elsewhere, but in negligible amounts (per unit surface) compared with that in the mesh.

At the end of the experiment approximately $60 \%$ of the availahle ${ }^{137} \mathrm{Cs}$ had transferred through the liquid/gas interfaces and had condensed on cold stainless steel walls. Approximately $5 \%$ remained in

Table III

Reduction in Sodium Contamination During Small Scale Loop Experiments

\begin{tabular}{|c|c|c|c|c|c|c|}
\hline \multirow[b]{3}{*}{ Experiment } & \multicolumn{4}{|c|}{$\begin{array}{c}\text { Sodium Contamination } \\
\text { (dis/min-g) }\end{array}$} & \multirow{2}{*}{\multicolumn{2}{|c|}{$\begin{array}{c}\text { Reduction } \\
\text { Factor }\end{array}$}} \\
\hline & \multicolumn{2}{|c|}{ Beginning } & \multicolumn{2}{|c|}{ End } & & \\
\hline & ${ }^{90} \mathrm{Sr}$ & ${ }^{137} \mathrm{Cs}$ & ${ }^{90} \mathrm{Sr}$ & ${ }^{137} \mathrm{Cs}$ & $90 \mathrm{Sr}$ & ${ }^{137} \mathrm{Cs}$ \\
\hline Zr Hot Trap & $3.21 \times 10^{6}$ & $4.71 \times 10^{6}$ & $1.52 \times 10^{4}$ & $2.34 \times 10^{5}$ & 212 & 20 \\
\hline Graphite Scavenger & $1.52 \times 10^{4}$ & $2.34 \times 10^{5}$ & $1.13 \times 10^{4}$ & $2.43 \times 10^{4}$ & 1.3 & 9.6 \\
\hline Ful1-Flow Cold Trap & $1.74 \times 10^{6}$ & $2.59 \times 10^{6}$ & $5.18 \times 10^{3}$ & $1.79 \times 10^{6}$ & 336 & 1.5 \\
\hline
\end{tabular}




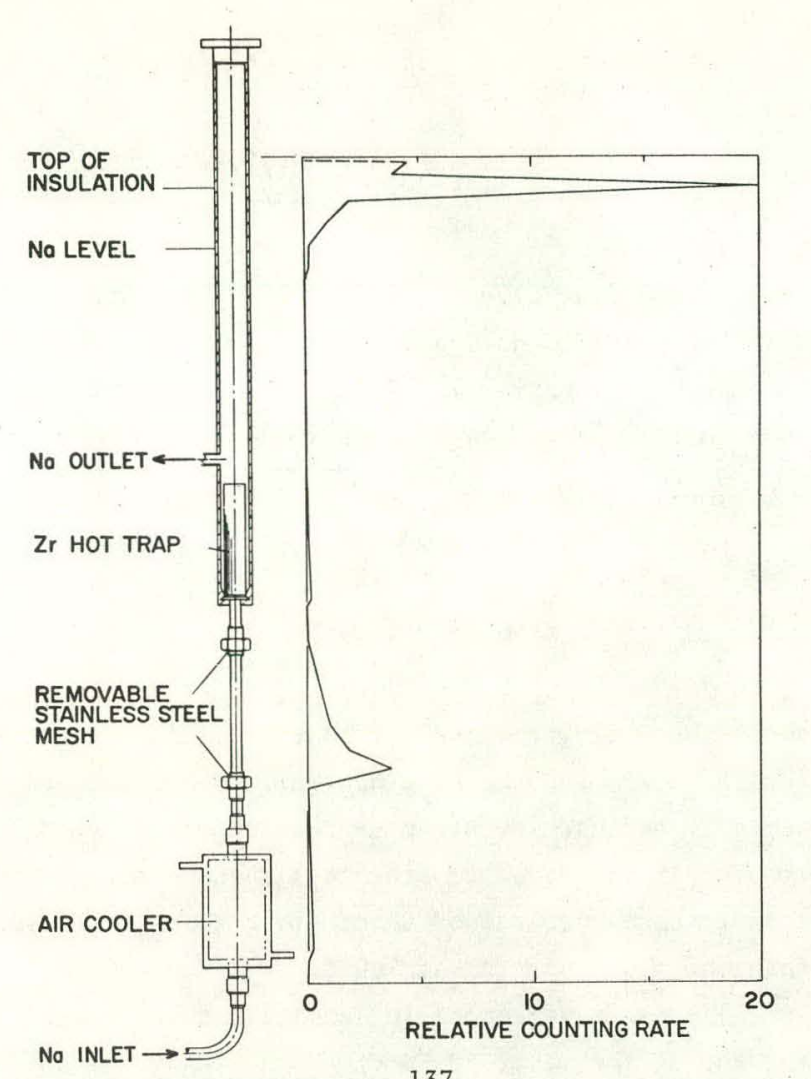

Fig. 4. Distribution of ${ }^{137} \mathrm{Cs}$ in the cold leg of a zirconium-gettered sodium loop.

solution in sodium, and the remainder was distributed among the two hot traps and the other sodiumwet surfaces of the loop. Both zirconium hot traps were analyzed radiochemically. Plutonium, ${ }^{90} \mathrm{Sr}$, and ${ }^{137} \mathrm{Cs}$ had segregated to the stainless steel portions of the trap that had operated at $300-500^{\circ} \mathrm{C}$. Contamination levels here were higher, by factors of 20-50, than in corresponding sections of the trap that had operated at $500-600^{\circ} \mathrm{C}$. Cesium was recovered from all metal surfaces without difficulty by alcohol rinse, while ${ }^{90} \mathrm{Sr}$ and plutonium required acid leaching.

\section{Graphite Bed}

To determine whether ${ }^{137} \mathrm{Cs}$ previously deposited on sodium-wetted stainless steel was recoverable, a bundlc of spectroscopic grade graphite rods was submerged in the cold leg of the loop. Figure 5 shows the activity distribution before graphite addition and a month later. The loop was operated in the $110-300^{\circ} \mathrm{C}$ range for a total of 50 days, and the graphite collected cesium from stainless steel tubing and mesh surfaces. The average contamination

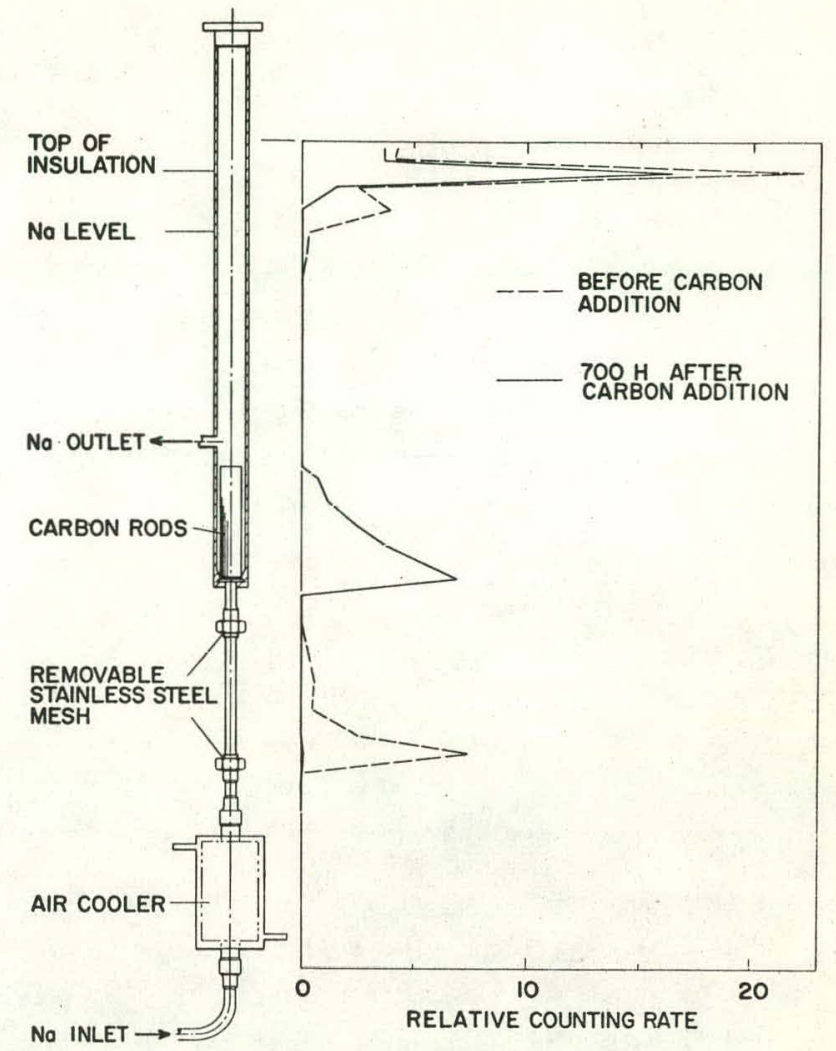

Fig. 5. Effect of graphite on the distribution of ${ }^{13} \mathrm{Cs}$ in the cold leg of a sodium loop.

level of the mesh surfaces was reduced by a factor of 40 , to a final value of $3.8 \times 10^{5} \mathrm{dis} / \mathrm{min}$-in. During this same 50 -day period the cesium activity at the walls in the gas space was reduced by half.

$\Lambda 1$ though the bed collected activity during the entire test period, an apparent redistribution of activity began $2 / 3$ of the way through the test.

The use of graphite to recover significant fractions of the ${ }^{137}$ Cs previously spread throughout a sodium system (in solution and on stainless steel surfaces) might be effective if it could be established that negligible carbon were introduced into solution and transported to surfaces where carburization could not be tolerated.

D. Full-Flow $\mathrm{Na}_{2} \mathrm{O}$ Cold Trap

To investigate the effect of cold trapping on ${ }^{90} \mathrm{Sr}$ and ${ }^{137} \mathrm{Cs}$ levels in sodium, a small full-flow cold trap was inserted in place of the removable trap section of the loop (Fig. 1).

A schematic of the trap appears in Fig. 6. The trap consists of a regenerative cooler and a thinwalled bulb filled with stainless steel mesh. With 


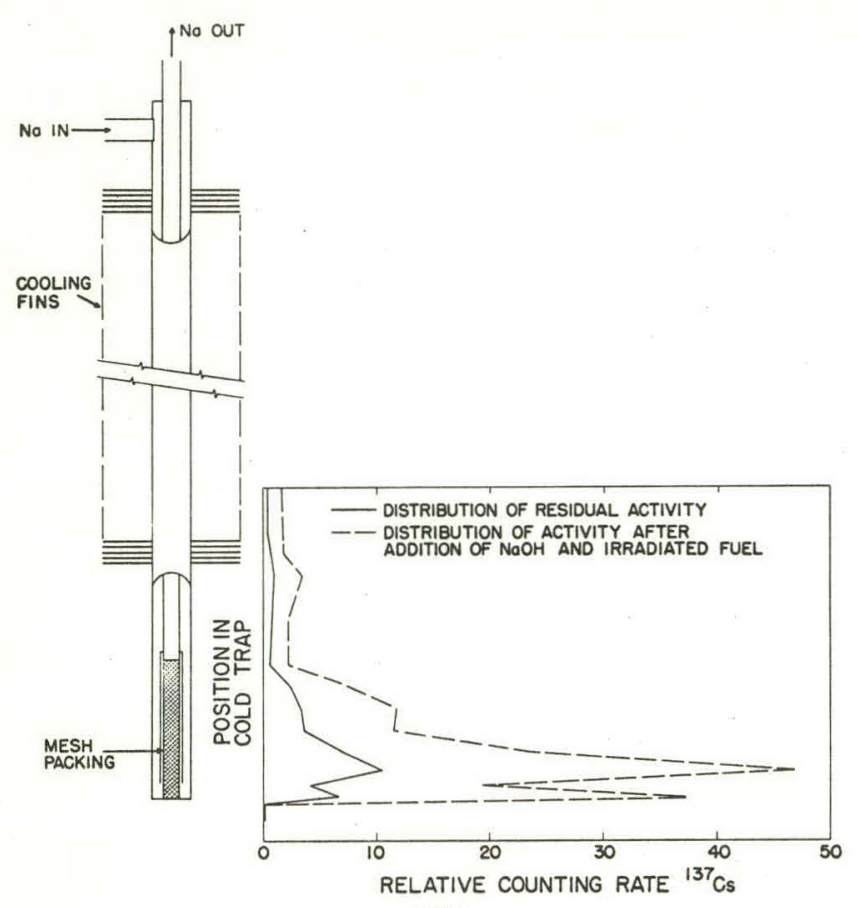

Fig. 6. Distribution of ${ }^{137} \mathrm{Cs}$ in cold trap.

the trap bulb operating at $175^{\circ} \mathrm{C}$, oxygen (as $\mathrm{NaOH}$ ) was added to the loop. The solid line on the graph (Fig. 6) shows the axial distribution of ${ }^{137}$ Cs scavenged from the loop during this period.

After the cold trap had stopped scavenging ${ }^{137} \mathrm{Cs}$, specimens of stainless steel mesh and additional trace-irradiated $\mathrm{Pu}$-Co-Ce were placed in the loop. The fuel and one mesh specimen were held at $500^{\circ} \mathrm{C}$, and the other mesh specimen was held at $300^{\circ} \mathrm{C}$. The axial distribution of ${ }^{137} \mathrm{Cs}$ in the cold trap 12 days after addition of fue 1 is represented by the dashed line in Fig. 6. The two distributions have the same characteristics; in each case the largest peak is associated with a spider used to maintain spacing between the concentric tubes in the bulb. The second peak is aligned with the inside bottom plate of the cold trap. The lowest peak occurs in the region where the shell covering the cooling fins is attached to the recuperator. Whether the ${ }^{137}$ Cs distribution is patterned after the distribution of sodium oxide is unknown. The distribution of activity did not change appreciably during the remaining $2-1 / 2$ months of operation. However, the total ${ }^{137}$ Cs activity in the trap was affected by small changes in trap temperature so that a steady-state condition was not attained. The distribution of ${ }^{137} \mathrm{Cs}$ and ${ }^{90} \mathrm{Sr}$ at the end of the test is shown in Table IV. The agreement be-
Table IV

Distribution of ${ }^{90} \mathrm{Sr}$ and ${ }^{137}$ Cs After Full-Flow Cold Trap Experiment

\begin{tabular}{cc}
${ }^{90} \mathrm{Sr}$ & ${ }^{137} \mathrm{Cs}$ \\
(dis/min) & (dis/min) \\
\hline
\end{tabular}

$\mathrm{Na}_{2} \mathrm{O}$ Trap Bulb

$2.69 \times 10^{7}$

$2.52 \times 10^{9}$

$\mathrm{Na}_{2} \mathrm{O}$ Trap Bleed Valve

$0.02 \times 10^{7}$

$0.60 \times 10^{9}$

Cold Leg Mesh (downstream) $1.60 \times 10^{7}$

Hot Leg Mesh (upstream)

$0.68 \times 10^{7}$

$0.48 \times 10^{9}$

Loop Sodium

$0.88 \times 10^{7}$

$0.02 \times 10^{9}$

Total

$5.87 \times 10^{7}$

$3.14 \times 10^{9}$

Fue 1 Pin Inventory before Test

$3.25 \times 10^{9}$

$6.76 \times 10^{9}$

$\%$ Activity Accounted for

$1.8 \%$

$7.64 \times 10^{9}$

$88.5 \%$

tween the ${ }^{90} \mathrm{Sr}$ recovered and that available from the fuel is poor, and the only appropriate observation seems to be that strontium segregated to the cold trap. Per unit area of stainless steel surface, the cold trap mesh contained about eight times more ${ }^{90} \mathrm{Sr}$ than the mesh operated at $500^{\circ} \mathrm{C}$.

The ${ }^{137}$ Cs agreement in Table IV is better. At the end of the test, $88.5 \%$ of the activity available from the fuel was recovered. Sodium in the loop contained $46 \%$ of the ${ }^{137} \mathrm{Cs}$ recovered, and the $\mathrm{Na}_{2} \mathrm{O}$ trap accounted for an additional 38\%. A 1/4-in.-diameter bleed line on the downstream side of the cold trap contained $9 \%$ of the activity, although there was no flow in this line during the experiment. The net amount of ${ }^{137} \mathrm{Cs}$ transferred from sodium to gasfilled sections was trivial.

The fact that a small diameter bleed line (whose activity pickup was diffusion-limited) contained $1 / 4$ as much ${ }^{137}$ Cs as the larger full-flow cold trap 1ocated upstream indicates that the full-flow trap was not a particularly effective scavenger. Whether the small amount of ${ }^{137}$ Cs transferred to the gas-filled section in this experiment (contrasted with the amount transferred in the hot trap experiment) results from lower sodium-gas interface temperatures or from the presence of a cold trap is unclear. (The transport of ${ }^{137}$ Cs from sodium to the vapor phase is being investigated in another portion of the program).

E. $\mathrm{Na}_{2} \mathrm{O}$ Diffusion Cold Trap Experiment

Because of the difficulty in maintaining close temperature control over the $\mathrm{Na}_{2} \mathrm{O}$ full-flow cold 
trap, a diffusion cold trap was substituted tö determine whether $\mathrm{Na}_{2} \mathrm{O}$ affects the distribution of ${ }^{137}$ Cs or whether the distribution is determined by temperature alone. The experiment consists of: (1) establishing an equilibrium with respect to ${ }^{137} \mathrm{Cs}$ before significant $\mathrm{Na}_{2} \mathrm{O}$ has been added to the trap, (2) adding large amounts of $\mathrm{NaOH}$ to the system in an attempt to upset this equilibrium and, (3) adding zirconium foil to the high temperature section of the loop to remove oxygen from the cold trap and observing any ${ }^{137} \mathrm{Cs}$ redistribution. At present the experiment is in the second phase.

SUMMARY AND CONCLUSIONS

1. The phenomena observed here are not novel. They have been reported in conjunction with reactor experiments in this country and abroad. The fact that similar behavior has been seen in these experiments adds weight to the belief that small scale studies can be useful.

2. The results of these experiments are interesting enough that a more systematic investigation of fission product distribution and trapping, is being undertaken, including determination of the shorter-lived isotopes ${ }^{131} \mathrm{I},{ }^{95} \mathrm{Zr}$, $140 \mathrm{Ba}$. The immediate goals are to identify sodium-soluble isotopes and to examine the effects of primary coolant system construction materials, design features, and operating conditions on these isotopes.

3. All isotopes for which data were obtained had segregated to the cold portions of the sodium system under all operating conditions. Appreciable fractions of the activities released to the sodium system were removed from solution by one means or another, although the effects of such variables as temperature, temperature gradient, and sodium purity are unknown. of the isotopes considered, on $1 y^{90} \mathrm{Sr}$ and ${ }^{137} \mathrm{Cs}$ appear to be of any consequence in the experiments.

4. The difficulty with which ${ }^{90} \mathrm{Sr}$ has been recovered from metal specimens, the low levels of ${ }^{90} \mathrm{Sr}$ contamination in sodium, and the lack of evidence for any redistribution of ${ }^{90} \mathrm{Sr}$ in the sodium system indicate that strontium, once depusited from sodium solution, is fixed in place. No attcmpt has yet been made to iden- tify deposition mechanisms or rates.

5. The ease with which ${ }^{137} \mathrm{Cs}$ has been recovered from analytical specimens, together with the migration of cesium from liquid to gas phase and its recovery within the sodium system by several techniques, suggests that it is very weakly adsorbed on sodium-wet surfaces. In these experiments cold trapping was the least effective method for reducing the ${ }^{137}$ Cs content of contaminated sodium. No attempt has been made, as yct, to identify ${ }^{137} \mathrm{Cs}$ deposition mechanism or rates. Although some rate data have been obtained for ${ }^{137} \mathrm{Cs}$, they are influenced to such a degree by the type of fuel used (i.e., liquid metal) and the experimental configurations that they have not been reported.

6. In interpreting these observations, it should be remembered that the source of activity was a liquid metal in which all fission products probably existed in the fully reduced state. Departures from this condition, brought about by substitution of oxide and carbide fuels for the liquid Pu-Co-Ce alloy, have not been discussed. 